\title{
FATIGUE STRENGTH IMPROVEMENT OF AISI E52100 BEARING STEEL BY INDUCTION HEATING AND REPEATED QUENCHING
}

\author{
E. C. SANTOS, K. KIDA, T. HONDA, H. KOIKE, J. ROZWADOWSKA \\ Kyushu University, Motooka, Fukuoka, Japan
}

\begin{abstract}
Martensitic high carbon high strength AISI E52100 steel (JIS SUJ2) is one of the main alloys used in rolling contact applications when high wear and fatigue resistance are required. In this work, repeated induction heating and quenching of AISI E52100 is proposed and the refinement of the martensite structure and consequently improvement of the fatigue properties measured by rotating bending fatigue tests of steel parts is reported.
\end{abstract}

Keywords: induction heating; repeated quenching; high carbon steel.

Induction heating has become widely available as an alternative to furnace heating for thermal processing of several materials, in particular steel parts [1]. Most steels with carbon content higher than $0.3 \%$ (wt.\%) are suitable for hardening by induction heating. Compared to conventional gas furnace heating treatment, this process offers several advantages such as fast heating rates, low energy consumption, and cost saving [1]. The fast heating rates result in structure refinement and better mechanical properties. Unconventional heat treatment based on temperature cycling is known to reduce prior austenite grain size (PAGS) in case of gas furnace treatment [2-5]; however there is still little research about the effect of repeated quenching by induction heating. Martensitic high carbon high strength AISI E52100 steel (JIS SUJ2) is one of the main alloys used in rolling contact applications when high wear and fatigue resistance are required [6]. In this work, repeated induction heating and quenching is applied to AISI E52100 samples and the influence of this combined process on the microstructure and fatigue strength is investigated.

Test material and experimental procedures. Material and specimens. The chemical composition (wt.\%) of the AISI E52100 steel bars was 1.0 C; $1.41 \mathrm{Cr}$; $0.35 \mathrm{Mn}$; $0.17 \mathrm{Si} ; 0.1 \mathrm{Cu} ; 0.016 \mathrm{Al} ; 0.02 \mathrm{Mo} ; 0.015 \mathrm{P} ; 0.006 \mathrm{Ni} ; 0.002 \mathrm{~S} ; 59 \mathrm{~N} ; 14 \mathrm{Ti}$ and $5 \mathrm{O}$ (Ti, O, N: ppm). Prior to induction heating the bars were annealed and the initial microstructure was confirmed to be formed by ferrite and spheroidized cementite particles. Two types of specimens were prepared: fatigue specimens were machined to fit the configuration shown in Fig. 1 and bar specimens of $20 \mathrm{~mm}$ in diameter were prepared for metallurgical observation. In each of the fatigue specimens a stress concentrator (slit of $0.8 \mathrm{~mm}$ length, $0.5 \mathrm{~mm}$ depth and $0.2 \mathrm{~mm}$ radius) was milled. The samples were mechanically polished before testing. Both bars and rotating bending fatigue specimens were processed by induction heating once (HT1), twice (HT2) and thrice (HT3). The induction heating power varied from $40 \mathrm{~kW}$ to $50 \mathrm{~kW}$ and the frequency was kept constant at $60 \mathrm{kHz}$. A photograph of the induction heating apparatus is shown in Fig. 2. The samples rotated at a speed of $300 \mathrm{rpm}$ as they passed through the coil at a translational speed of $35 \mathrm{~mm} / \mathrm{s}$. The rotating bending machine was designed in-house to test sample as large as $10 \mathrm{~mm}$ to $30 \mathrm{~mm}$ in diameter and $20 \mathrm{~cm}$ to $50 \mathrm{~cm}$ in length. Photographs of the machine can be seen in Fig. 3 .

Corresponding author: E. C. SANTOS, e-mail: santos@mech.kyushu-u.ac.jp 

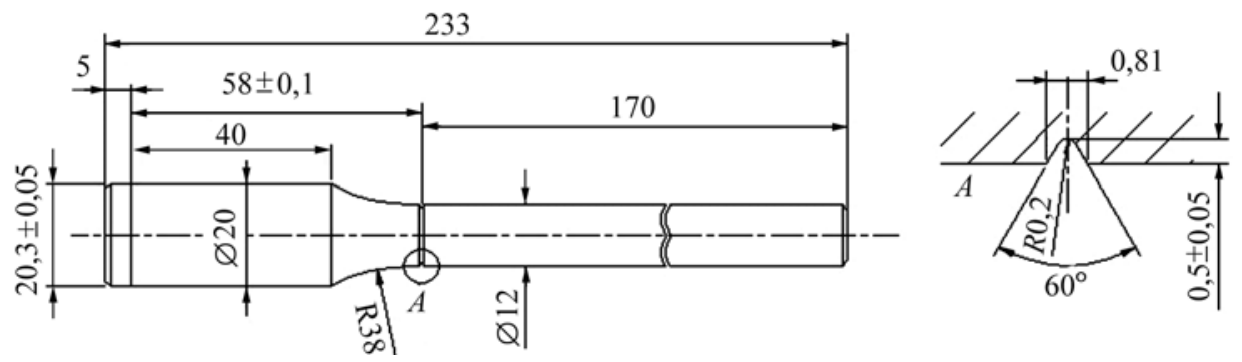

Fig. 1. Geometry of the rotating bending samples with a slit. All dimensions in mm.

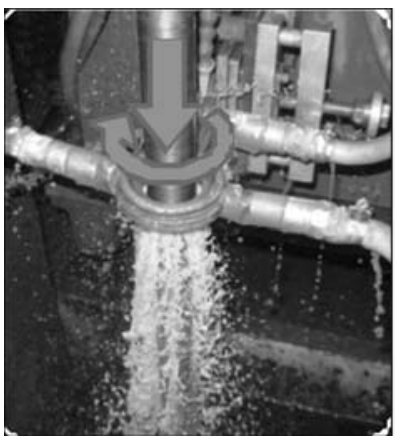

Fig. 2.
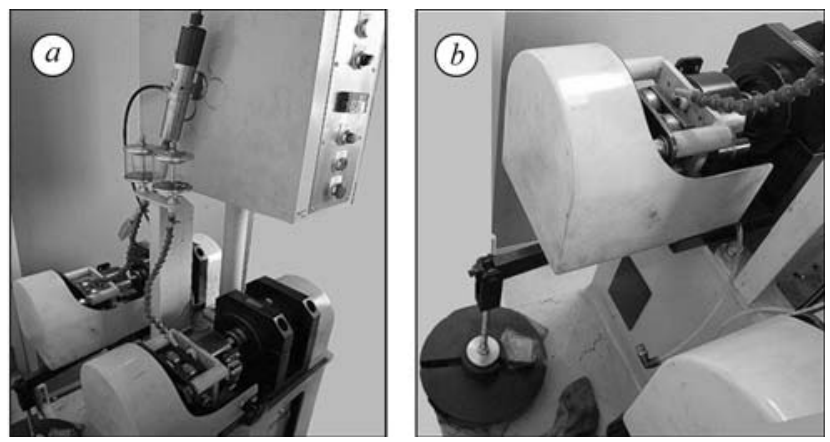

Fig. 3.

Fig. 2. Photo of the induction heating process.

Fig. 3. Photos of the rotating bending machine $(a)$ and detail of the sample holder and load $(b)$.
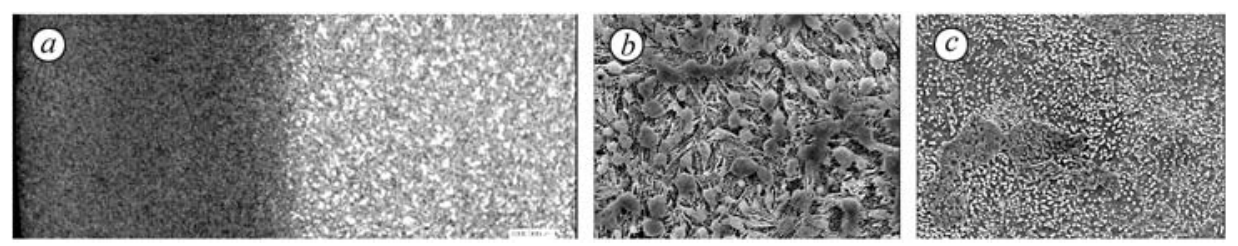

Fig. 4. Microstructure of the samples quenched once and etched by Nital $6 \%$ observed by laser confocal microscope and scanning electron microscope: $a$ - laser confocal microscope image of the transformed area; $b$-FEG-SEM high magnification image of the martensitic transformed area; $c$-FEG-SEM image of the microstructure of the ferrite + cementite core.

Microstructure and hardness. The martensite and retained austenite were observed by a laser confocal microscope (LCM) and scanning electron microscope (SEM). The samples were etched by immersion in Nital $6 \%$ for 10 to $20 \mathrm{~s}$. The prior austenite grain size was observed in samples etched by immersion for $5 \mathrm{~min}$ in a Van Giesson picral solution plus $2 \mathrm{ml}$ of Teepol wetting agent and 2 drops of $\mathrm{HCl}$ followed by final polishing with Buehler's Mastermet 2 colloidal silica suspension. The martensitic structure was also observed by electron backscatter diffraction using a Digiview TSL detector in a Hitachi SU6600 FEG-SEM. The probe current was measured as $10 \mathrm{nA}$. An area of $30 \times 30 \mu \mathrm{m}$ located at $0.2 \mathrm{~mm}$ from the edge of each sample was measured by EBSD. The step size was $50 \mathrm{~nm}$. The micro Vickers hardness profile of the samples was also measured after repeated induction heating.

$X$-ray measurements. X-ray diffraction was used to measure the amount of retained austenite and residual stress before and after the rotating bending tests. A Bruker D8 discover with GADDS (2D detector) was used. The X-ray tube equipped with $\mathrm{CrK}_{\alpha}$ radiation operated at $35 \mathrm{kV} / 40 \mathrm{~mA}$. A graphite monochromator was positioned at the incident beam. The detector distance was $15 \mathrm{~cm}$, this corresponds to a $\pm 15^{\circ}$ range from the centre of the detector. The measurements of retained austenite and resi- 
dual stress were performed using a $100 \mu \mathrm{m}$ collimator. During the retained austenite measurements, the $2 \mathrm{D}$ detector was positioned at $2 \theta=75^{\circ}$ (measurement region from $60^{\circ}$ to $90^{\circ}$ ) and $\omega$ was scanned from $30^{\circ}$ to $45^{\circ}$. The collecting time was 1 hour. The martensite $\alpha$-Fe 110 and austenite $\gamma$-Fe 111, $\gamma$-Fe 200 peaks were fitted and quantified by Rietveld refinement using TOPAS-academic. During the residual stress measurements, the $2 \mathrm{D}$ detector was positioned at $2 \theta=-143^{\circ}$ (measurement region from $-128^{\circ}$ to $\left.-158^{\circ}\right)$. The martensite $\alpha-\mathrm{Fe} 211$ at $156^{\circ}$ was used as a standard. The residual stress was measured by biaxial mode using 21 frames varying $\chi$ from $90^{\circ}$ to $30^{\circ}$ and $\omega$ from 0 to $180^{\circ}$. The collecting time was $7 \mathrm{~h}(1200 \mathrm{~s}$ per frame). Residual stress was calculated using Bruker's Leptos 6.3, Pearson VII function.

Results and discussion. Fig. 4 shows the top surface of the once quenched bar samples after etching in Nital 6\%. By repeated quenching, the depth of transformation increased slightly: from $1.16 \mathrm{~mm}$ (quenched once) to $1.25 \mathrm{~mm}$ (quenched thrice). Fig. $4 a$ presents the laser confocal microscope image of the transformed area. The transformed area is composed of lath and plate martensite (Fig. 4b) while the core is formed by ferrite and sphereodized cementite (Fig. 4c). The cementite vol.\% and inclusion average size were measured by SIGMASIS software [7]. The cementite morphology and content remained unchanged by repeated quenching: the vol.\% was around $12 \%$ and the average size was $0.4 \mu \mathrm{m}$ independent of the number of quenching steps. Several different etchants were used in the attempt to measure the influence of the repeated quenching process on the prior austenite grain size. The best results were achieved by using the picral solution specified in the experimental procedures. Fig. 5 shows the micrographs of the samples after quenching once and thrice. The prior austenite grain size is reduced by the repeated quenching process.
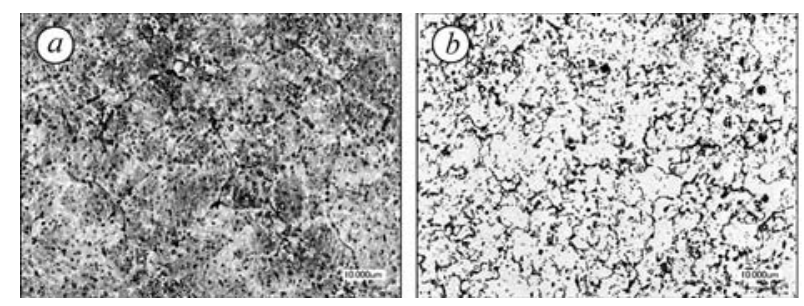

Fig. 5. Prior austenite grain size of samples quenched once $(a)$ and thrice $(b)$ showing refinement of the structure.

The prior austenite grain size suggests that the microstructure was refined; however, even comparing high resolution FEG-SEM microstructure, the refinement of the martensitic structure is not clear. Fig. 6 shows the electron backscatter diffraction maps (orientation image mapping) of samples HT1, HT2 and HT3. The micrographs clearly indicate that the microstructure was refined by repeated quenching.
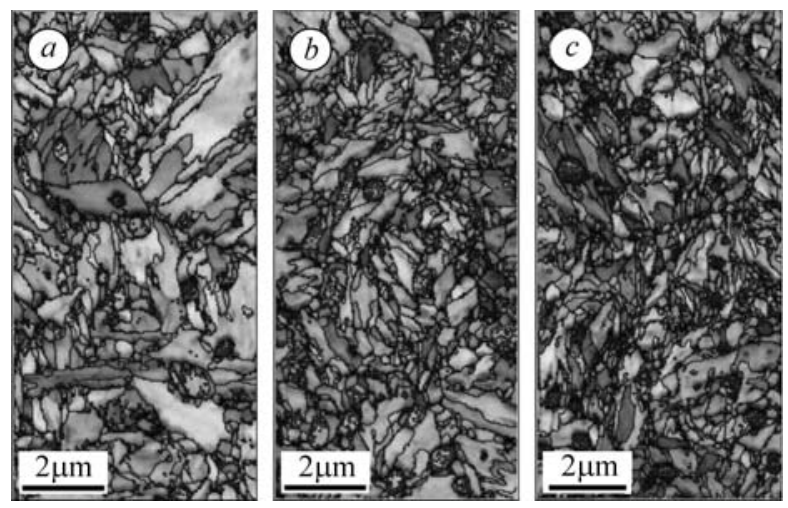

Fig. 6. Orientation image mapping (OIM) of samples HT1(a), HT2 (b) and HT3 (c) showing refinement of the microstructure by repeated quenching. 
Fig. 7 shows the diffraction pattern of samples HT1, HT2 and HT3. The amount of the retained austenite increased from $32 \%$ (HT1) to $41 \%$ (HT3). The retained austenite content was slight higher in sample HT3 compared to HT2. Due to the competition between nucleation of new austenite grains and grain growth that occur simultaneously, quenching more than two or three times does not induce significant microstructure changes in the material.

The residual stress measurement at the top surface of the samples can be seen in Table. Stress $\sigma_{11}$ was in the tangential and $\sigma_{22}$ in the radial direction. In the tangential direction $\left(\sigma_{11}\right)$, the stresses were always compressive. The residual stresses in the radial direction $\left(\sigma_{22}\right)$ were close to zero.

\section{Residual stress measurements}

\begin{tabular}{|c|c|c|}
\hline & $\sigma_{11}, \mathrm{MPa}$ & $\sigma_{22}, \mathrm{MPa}$ \\
\hline HT1 & $-228.6 \pm 10.4$ & $43.0 \pm 9.0$ \\
\hline HT2 & $-149.7 \pm 12.7$ & $21.2 \pm 11.0$ \\
\hline HT3 & $-106.7 \pm 13.3$ & $13.1 \pm 11.5$ \\
\hline
\end{tabular}

The hardness distribution remained unchanged by the repeated quenching process. Fig. 8 shows the hardness distribution after quenching once, twice and thrice. The maximum hardness occurs around 0.3 to $0.6 \mathrm{~mm}$ inside the material. The lower hardness at the surface might be a result of decarburization and/or non-uniform distribution of the carbon content prior to induction heating. Austenite nucleation and grain growth occurs when the temperature reaches $A_{c 1}$ and due to temperature variation from the surface to the core of the sample, the hardness will be non-uniform. It is important to notice that even with a $9 \%$ increase in the retained austenite content, the hardness distribution did not change possibly due to the structure refinement.

The $S-N$ curves of the samples measured by rotating bending can be seen in Fig. 9 . The improvement of the fatigue strength as a result of the repeated quenching is clear. The higher retained austenite content and the refinement of the martensite structure were effective to increase the fatigue strength of the samples.

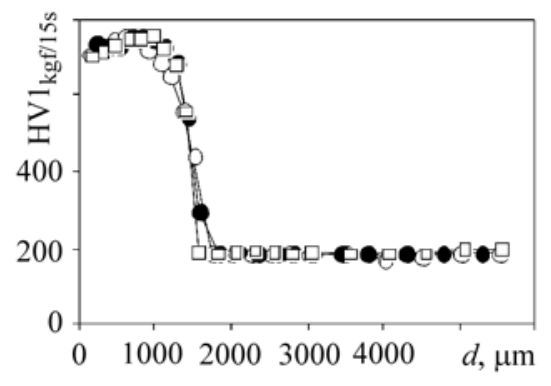

Fig. 8 .

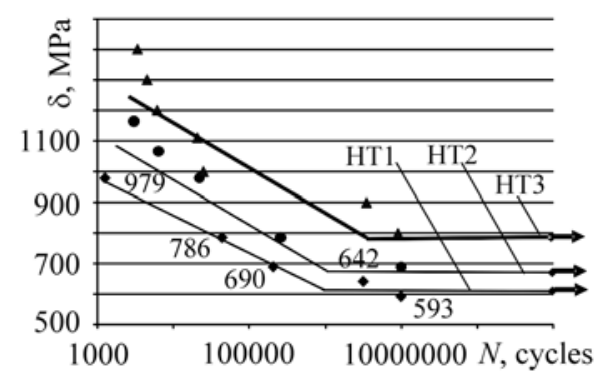

Fig. 9.

Fig. 8. Hardness distribution in the samples quenched once HT1 (०), twice HT2 (•) and thrice HT3 ( $\square)$.

Fig. 9. $S-N$ curve of samples after repeated quenching measured by rotating bending test. 


\section{CONCLUSIONS}

Repeated induction heating and quenching was applied to AISI E52100 shafts. The microstructure of the material was observed by laser confocal microscopy, scanning electron microscopy and orientation image mapping. The hardness, retained austenite content, residual stresses and fatigue properties were measured. The repeated quenching process decreased the prior austenite grain size and consquently refined the martensitic structure of the samples. The retained austenite content increased. Residual stresses were compressive in the tangential and close to zero in the radial direction. The refinement of the martensitic structure and higher content of retained austenite after quenching thrice increased the fatigue strength of the material.

РЕЗЮМЕ. Високовуглецеву високоміцну мартенситну сталь AISI E52100 (JIS SUJ2) найчастіше використовують за умов контактного кочення, де необхідні підвищені зносотривкість та втомна міцність. Запропоновано методи повторного індукційного нагріву та гартування сталі, внаслідок чого подрібнюється структура мартенситу та поліпшуються втомні властивості під час випробувань сталевих зразків за циклічного згину.

PЕЗЮМЕ. Высокоуглеродистую высокопрочную мартенситную сталь AISI E52100 (JIS SUJ2) наиболее часто используют в условиях контактного качения, когда необходимы повышенные износостойкость и усталостная прочность. Предложены методы повторного индукционного нагрева и закаливания стали, вследствие чего измельчается структура мартенситна и улучшаются усталостные свойства во время испытаний стальных образцов при циклическом изгибе.

Acknowledgements. The authors would like to thank Mr. Kinoshita from Keyence and Dr. Saito from Bruker for the help with the laser confocal microscope and $x$-ray measurements, respectively. We would also like to express our gratitude to Dr. Suzuki from TSL Japan for the EBSD measurements and Mr. Shibukawa from YSK, Co., Ltd., for providing the heat treated samples.

1. Haimbaugh R. E. Practical induction heat treating // ASTM International. - 2001.

2. Mazanec K. and Mazancova E. Physical metallurgy of thermomechanical treatment of structural steels // Cambridge International Science Publishing. - 1997.

3. Smoljan B. An analysis of combined cyclic heat treatment performance // J. Mater. Process. Tech. - 2004. - 155. - P. 1704-1707.

4. Nakazawa K., Kawabe Y., and Muneki S. Grain refinement of high-strength maraging steels through cycle heat treatment // Mater. Sci. Eng. - 1978. - P. 49-56.

5. Padmanabhan R. and Wood W. E. Microstructural analysis of a multistage heat-treated ultrahigh strength low alloy steel // Mater. Sci. Eng. - 1984. - 66. - P. 125-143.

6. Crack initiation from micro surface holes in bearings under rolling contact fatigue / K. Kida, T. Yamazaki, M. Shibata, N. Oguma, and H. Harada // Fatigue \& Fract. Eng. Mater. Struc., Blackwell Publishing. - 2004. - 27. - P. 481-493.

7. SIMAGIS ${ }^{\circledR} 4.0$, Smart Image Technology, http://smartimtech.com. 